\title{
Discuss Whether Incentive Executive Compensation Poses Governance Issues
}

\section{Abbott Haron*}

Higher Colleges of Technology, Business Higher Colleges of Technology, Sharjah Women's College, University City Sharjah, Sharjah, United Arab Emirates

Executive compensation structures (joined with bank accounting regulations) encouraged the delivery of misleading information booking income "above the line," however retaining liabilities off the balance sheet [1]. Executives paid with stock options are motivated to increase the market value of shares, and this may be more simply done by increasing reported income than by increasing true profits. Though Sarbanes-Oxley fixed some of the problems that were uncovered in the Enron and associated scandals, it did nothing about stock options. With stock options not being expensed, shareholders frequently were not fully apprised of their cost. This provides durable incentives to pay exorbitant compensation through stock options. However, the use of stock options emboldens bad accounting practices [1].

In addition, stock options, where executives only share in the gains, but not the losses, and even more so, similar bonus schemes widespread in financial markets, provide strong incentives for excessive risk taking. These might gather more profits in the short term, thereby increases compensation; but succeeding losses were endured by others. In a sense, they were intended to encourage risk taking. The problem is that they encouraged excessive risk taking [2].

One major example of this type of risk taking was the most cause of the financial crisis in 2007 and 2008, the price of the typical American house increased by $124 \%$. In search of the American Dream, homeowners were purchasing homes that they could not afford. To make matters worse, mortgage executive and brokers were giving out sub-prime mortgages and even liar loans. Liar loans refer to loans given for borrowers who have an unstable source of income, or have trouble producing asset-verifying documents, such as prior tax returns. Consequently, banks would purchase these subprime mortgages from brokers in order to resell them to investors. In essence, all the parties involved were passing down the risk to the next party in line, all to make quick profits in the short terms so the executives share and compensation can go up [3].

Discuss whether you believe the public company auditors did their job or were contributory in the financial meltdown of 2008-2009.

From 1993 to 1997 Arthur Andersen was the internal auditor to the Audit Commission in the United Kingdom. The ultimate ombudsman of all public finances. In the meantime, towards the end of this period, one is reminded, Andersen was inserting its tentacles into the next Government by training 100 new Labour MPs on management practices for when they took power in the British parliament [4]. Keeping in mind that Arthur Andersen was the internal auditor for Enron, one of the biggest corporate failures in modern history [5].

Even after the Enron and WorldCom disasters, the Securities and Exchange Commission announced that it would continue to accept financial statements audited by Andersen, if the companies filing the statements obtain from Andersen certain representations concerning audit quality and controls, and generally set forth those representations in their filings. This should shed some light as to the level of carelessness that was the catalysts to the economic meltdown of 2008 [5].

The global financial crisis began around 2007 and was considered the worst financial crisis since the Great Depression of the 1930's. Many economists have debated about the role of accountants in the financial crisis. More specifically, some economists tried to pinpoint the role of auditors. Some economists argued that the lack of transparency in companies' financial statements led to the financial crisis [3]. Many companies and banks collapsed or almost did because of weak financial audits [2]. Indeed, one can say that auditors should have been more involved in the prevention process. However, had auditors not been around, the financial crisis would have been even devastating [3].

An auditor's role is not to forecast the future but to confirm that companies' financial statements give a true and fair view of the fiscal year performance. The primary role of auditors is to decide if an entity's financial statements are free of material misstatements. Their role is not to spot fraud, but to determine if the company's financial statements are factual and fairly presented. However, many auditors failed to distinguish the bad lending practices that led to the housing bubble and breakdown [6].

Furthermore, the audit process is increasing its use of the checklist technique. Where this method helped to determine if loans were recorded, it did not force auditors to look beyond the given number to test the legitimacy of the numbers. In the course of understanding the business, the auditors should have realized that this type of lending practice did not have a solid footing. Many of the companies that received an unreserved opinion may not have deserved a clean opinion upon closer examination. Nevertheless, since the financial statements of those companies were "fairly presented" according to generally accepted accounting principles (GAAP), their lending practice flaws were not brought to light. Audits should have been a better lever to prevent the mistakes of some companies' financial situation if its professional standards were more successfully applied [3].

The audit market faces a number of weaknesses, which in our opinion made the call for transparency even harder to hear, these are weaknesses, are as follows: A lack of choice for audit clients consequential from high concentration levels, in essence an oligopoly; systemic risk if one of "the Big Four" (Deloitte, Ernst and Young, KPMG and PwC) fails. In that case, there would be even more concentration at the top end of the audit marketplace; possible conflicts of interest and issues around the objectivity of auditors; doubts around the credibility and dependability of the audited financial statements of

*Corresponding author: Abbott Haron, Business Faculty, Higher Colleges of Technology, Business Higher Colleges of Technology, Sharjah Women's College, University City Sharjah, Sharjah, United Arab Emirates, Tel: + 971505072291;E-mail: abbottjharon@gmail.com

Received December 05, 2014; Accepted May 18, 2015; Published June 05, 2015

Citation: Haron A (2015) Discuss Whether Incentive Executive Compensation Poses Governance Issues. J Bus Fin Aff 4: 137. doi:10.4172/2167-0234.1000137

Copyright: () 2015 Haron A. This is an open-access article distributed under the terms of the Creative Commons Attribution License, which permits unrestricted use, distribution, and reproduction in any medium, provided the original author and source are credited. 
Citation: Haron A (2015) Discuss Whether Incentive Executive Compensation Poses Governance Issues. J Bus Fin Aff 4: 137. doi:10.4172/21670234.1000137

Page 2 of 2

banks, other financial institutions and listed companies. These came in for substantial criticism during the crisis [7].

\section{References}

1. Stiglitz JE (2009) the financial crisis of $2007 / 2008$ and its macroeconomic consequences. Columbia University Academic Commons.

2. Norgren C (2010) The Causes of the Global Financial Crisis and Their Implications for Supreme Audit Institutions. Swedish National Audit Office. Stockholm.

3. Shi Y (2011) The Role of Auditors in the Current Financial Crisis. Fisher School of Accounting, Florida, USA.
4. Waller M (2002) Strange but true. From 1993 to 1997 Arthur Andersen was the internal auditor to the Audit Commission. The Times, 27. News International Trading Limited, London, United Kingdom.

5. Anonymous (2002) Arthur Andersen. ABA Bankers News, 10, 7, 2. ProQuest Central.

6. Anonymous (2011) The Watchdog that Didn't Bark Again. PCAOB Investor Advisory Group.

7. Anonymous (2011) Reforming the Audit Market - Frequently Asked Questions European Commission. 